NBER WORKING PAPER SERIES

\title{
WHAT IS A COMPANY REALLY WORTH? INTANGIBLE CAPITAL AND THE "MARKET TO BOOK VALUE" PUZZLE
}

\author{
Charles R. Hulten \\ Xiaohui Hao \\ Working Paper 14548 \\ http://www.nber.org/papers/w14548 \\ NATIONAL BUREAU OF ECONOMIC RESEARCH \\ 1050 Massachusetts Avenue \\ Cambridge, MA 02138 \\ December 2008
}

The research reported in this paper was sponsored by the Economics Program of The Conference Board, as part of its Program on Intangibles. It is derived from an earlier Economics Program working paper, $\# 08-02$. Hulten is Senior Fellow to The Conference Board. We would like to thank Wesley Cohen, Martin Fleming and Baruch Lev for their comments on earlier drafts, as well as Gail Fosler, Bart Van Ark, Carol Corrado, and other colleagues at the Conference Board. Kathleen Miller and Mary Sinclair provided valuable assistance in preparing this paper. Opinions and interpretations, and any remaining errors, are solely the responsibility of the authors, and should not be attributed to any organization with which they are affiliated, nor to the National Bureau of Economic Research.

NBER working papers are circulated for discussion and comment purposes. They have not been peerreviewed or been subject to the review by the NBER Board of Directors that accompanies official NBER publications.

(C) 2008 by Charles R. Hulten and Xiaohui Hao. All rights reserved. Short sections of text, not to exceed two paragraphs, may be quoted without explicit permission provided that full credit, including $\odot$ notice, is given to the source. 
What is a Company Really Worth? Intangible Capital and the "Market to Book Value" Puzzle Charles R. Hulten and Xiaohui Hao

NBER Working Paper No. 14548

December 2008

JEL No. G3,M41,O30

\begin{abstract}
$\underline{\text { ABSTRACT }}$
"What is a company really worth?" is a question asked repeatedly during the recent financial crisis. Attention has been focused on short-term valuation issues, like the "mark-to-market" controversy. Sorting out these issues is complicated by the fact that the market puts a value on shareholder equity that is consistently more than twice the reported book value of a company. Numerous observers have pointed to the absence of most intangible assets from financial statements as an important source of this puzzle. We use Compustat financial data for $617 \mathrm{R} \& \mathrm{D}$ intensive firms to test this possibility. We find that conventional book value alone explains only 31 percent of the market capitalization of these firms in 2006, and that this increases to 75 percent when our estimates of intangible capital are included. The debt-equity ratio also falls from 1.46 to 0.61 . These findings suggest that financial reports tend to substantially understate the long-run intrinsic value of corporate America.
\end{abstract}

Charles R. Hulten

Department of Economics

University of Maryland

Room 3105, Tydings Hall

College Park, MD 20742

and NBER

hulten@econ.umd.edu

Xiaohui Hao

The Conference Board

845 Third Avenue

New York, NY 10022

Janet.Hao@conference-board.org 


\section{Introduction}

"What is a company really worth?" is a question that has been asked repeatedly during the recent financial crisis. The market place provides a compelling answer: a company and its assets are worth only what the highest bidder is willing to pay. In theory, this value should equal the expected discounted present value of the future earnings, sometimes thought of as the intrinsic or "holding" value of the assets. In practice, it does not. During periods of market turbulence, the two valuations can diverge significantly because of asymmetrical information and liquidity constraints. The recent "mark-to-market" debate is largely about which approach provides the more accurate reflection of fair value when markets are volatile. This debate is complicated by the fact that, even in calmer times, there is the "market-to-book value" puzzle to explain.

This puzzle arises because the market consistently puts a higher value on shareholder equity than the value appearing on corporate balance sheets. The average price-to-book ratio for the companies of the S\&P 500 index ranged from around 2.0 to 3.5 in the period 1990-1995, and increased to the 3.5-7.5 range during the "tech boom" period 1996-2000 (Lev (2001)). Even during the recent stock market slump, the ratio has remained in the range of 1.5 to 2.0 .

This price-to-book gap is too large to be attributed solely to the mismeasurement of conventional equity or to the vicissitudes of the stock market. Numerous observers, including Lev, have pointed to absence of intangible assets from corporate balance sheets as an important source of the puzzle. The billions of dollars companies spend 
on R\&D and brand development are treated as current expenses by their accountants largely because there are no market transactions to measure the value of R\&D and brand created within the company. The current success of many companies and their prospects for the future, however, depend on their ability to develop and market products, not just the ability to manufacture them. Portraying the product development only as a current expense without recognizing its contribution to future value conceals much of what makes a company successful and valuable in the long run. ${ }^{1}$

How much of the market-to-book value puzzle can be explained by intangible assets is the question examined in this paper. We approach the problem by applying procedures similar to those used by Corrado, Hulten, and Sichel (2006) to financial data for 617 R\&D-intensive corporations complied by Standard and Poor's in its Compustat database. $^{2}$ We construct estimates of the cost of in-house investment in R\&D and organizational capital using data for the period from 1988 to 2006, and then estimate the corresponding stocks in current prices. We find that the addition of these intangibles to the conventional financial accounts increases shareholder equity by 141 percent and total assets by 57 percent in 2006, and increases the earnings per share from an average of $\$ 2.48$ to $\$ 3.54$.

1 A growing literature explores the problem of accounting for intangibles in financial reports and valuing intangibles in the stock market, building on an earlier literature that examined the impact of R\&D and advertising on the rate of profit (e.g., Grabowski and Mueller (1978)). Important overviews are provided by Lev (2001) and Blair and Waldman (2001). The literature on the economics of intangibles is reviewed in Corrado, Hulten, and Sichel $(2005,2006)$, and in the introductory comments of Corrado, Haltiwanger, and Sichel (2005).

2 Recent estimates by Corrado, Hulten, and Sichel (CHS $(2005,2006))$ suggest that there were approximately $\$ 3.6$ trillion in intangible assets in the U.S. nonfarm business sector in the period 20002003 , compared with some $\$ 11$ trillion in tangible plant and equipment. These estimates cover both corporate and noncorporate companies, although corporations accounted for some three-quarters of the total, according to the Bureau of Economic Analysis figures. The large size of the aggregate effect suggests that the average impact on the individual corporations in the non-farm business sector is also large. 
As for the market-to-book value puzzle, we find that conventionally-defined equity alone explains 31 percent of market capitalization, and this increases to 75 percent when intangible capital is added to the balance sheets. This fills a significant part of the valuation gap and, more importantly, suggests that current financial practice understates the long-run intrinsic value of corporate America by a substantial amount.

Another implication of this line of analysis is that the degree of leverage, a closely watched indicator of financial health during the financial crisis, is significantly lower when intangibles are counted. For our sample of R\&D intensive companies, largely outside the financial sector, the debt-equity ratio falls from 1.46 to 0.61 when intangible assets are added to both numerator and denominator of the ratio. In other words, when the equity hidden in intangibles is put on display, the presence of debt on the balance sheet takes on a different significance for long-run valuation.

The following sections of this paper describe the details underlying these estimates. We start with the case of a representative company in one year as a concrete illustration of the issues in capitalizing internally produced intangibles. We then move to a parallel analysis of the universe of R\&D-intensive companies included in the S\&P database. Finally, we use our data to examine the correlation between our intangible capital stocks and market valuation to establish that intangibles are, indeed, capital. 


\section{The Case of a Representative R\&D-Intensive Company}

A. Revenue With and Without Intangibles

The case of a pharmaceutical company, PHARMA, illustrates the problems of recognizing intangibles. PHARMA operates in the pharmaceutical industry, one of the most R\&D-intensive industries of the U.S. economy. ${ }^{3}$ According to the composite annual financial statements, PHARMA revenues totaled $\$ 29.6$ billion in 2006 . The cost of goods sold was $\$ 6.4$ billion. R\&D and sales and administrative expenses (SG\&A) totaled $\$ 13.7$ billion, or nearly half of total sales. After subtracting depreciation, taxes, and other adjustments, after-tax income was $\$ 5.5$ billion and earnings per share (EPS) amounted to $\$ 2.03$. PHARMA reported total assets of $\$ 50.9$ billion on its balance sheet in 2006, of which property, plant and equipment accounted for $\$ 10.1$ billion. These data are shown in summary in Tables 1 and 2 , in the first column labeled "10k".

This is the standard version of PHARMA's 2006 financial report, following the convention that financial reports treat R\&D expenditures as a current expense and subtracts them from the sales figure on the top line. In this paper, we treat R\&D as an investment in the company instead of a pure cost and examine what effect this has on

3 PHARMA is a composite of six large companies in the U.S. pharmaceutical industry: Abbott Laboratories, the Bristol-Myers Squibb Company, Eli Lilly and Company, Johnson and Johnson, Pfizer Inc., and Wyeth. The financial statements of PHARMA are based on an average of the publicly available income statement and balance sheets of these six companies, supplemented by external estimates and assumptions. This averaging procedure attenuates the effects of firm-specific events like mergers and acquisitions, and special items on the financial statements of the individual companies. The name PHARMA is an expository invention of this paper and should not be associated with the Pharmaceutical Research and Manufacturers of America (PhRMA), or any other organization or company.

Other R\&D-intensive industries could have been used for expositional purposes, but the pharmaceutical industry was selected because it has a rich publicly available data and because it has an impressive track record of innovation. The pharmaceutical industry also illustrates the problem that R\&D investment has long gestation lags.

${ }^{4}$ We refer to PHARMA as a pharmaceutical company in this paper, but the pharmaceutical segment of PHARMA accounted for 75 percent of total 2006 revenue, while other segments, including other medical and consumer products, accounted for the rest. 
the company's financial accounts. We will show that this alternative view of R\&D involves an expanded concept of "output" and "revenues," and, since this shift involves a significant departure from current practice, we illustrate the issues involved with the following thought experiment.

First, suppose that PHARMA were to purchase $\$ 10$ million in tangible capital from another company, for example, a technologically advanced piece of laboratory equipment. The standard economic assumption underlying this purchase is that PHARMA invests up to the point that the $\$ 10$ million cost of the new equipment equals the discounted present value of the expected future profits created by the investment. ${ }^{5}$ Under conventional accounting practice, the investment would be added to PHARMA's balance sheet at its cost of $\$ 10$ million and amortized over time.

PHARMA's accountants do not treat the $\$ 10$ million tangible capital investment as an expense before figuring profit, but the company that sells the equipment to PHARMA does recognize the cost of producing the investment good as an expense and adds the $\$ 10$ million sale to its revenues. If the cost is, say, $\$ 8$ million, it records a before-tax profit of $\$ 2$ million.

\footnotetext{
${ }^{5}$ This is the usual "neoclassical" formulation, in which arbitrage across alternative investments equates the opportunity cost of an investment, the $\$ 10$ million, with the discounted present value of the expected income generated by the investment. As noted in the introduction, the recent crash in the equity and credit markets is a reminder that the ex ante expectations built into the original cost of an investment are not necessarily equal to ex post outcomes (the mark-to-market versus intrinsic value approach to asset valuation). In the best of worlds, it would be helpful to have accurate information on both ex ante and ex post asset values, because it would also give estimates of the implied ex ante and ex post rates of return on intangible projects. Unfortunately, it is hard to "mark to market" assets for which there is no market at all, and the present value approach is impossible to implement from externally available data. We therefore use the original cost of the owner-produced intangibles as our valuation metric.
} 
Now suppose that PHARMA contracts with another company, call it R\&DCOR, to conduct $\$ 10$ million in research on PHARMA's behalf. ${ }^{6}$ How does this situation differ from the case of the laboratory equipment? One possibility is that the purchased R\&D is an intermediate input to PHARMA's production, that is, an input that is used up like office supplies in the year in which they are delivered. However, this is inconsistent with the evidence presented in DiMasi (2001), who shows that the gestation period for a drug to make through the FDA approval process was 14.2 years during the 1980 s and 1990s (3.8 years for the pre-clinical phase, 8.6 for the clinical trials, and 1.8 for the approval phase). These gestation lags essentially refute the idea that $R \& D$ is an intermediate input that disappears within a year, and virtually force the recognition that the $\$ 10$ million in purchased R\&D is an investment made in order to earn future profits. From an economic standpoint, it is no different than a $\$ 10$ million investment in tangible laboratory equipment.

As with the laboratory equipment, the company producing the R\&D (R\&DCOR) treats the $\$ 10$ million received from PHARMA as revenue and allocates $\$ 8$ million to the cost of producing the R\&D and records a $\$ 2$ million before-tax profit. Moreover, if the financial statements of PHARMA and R\&DCOR were combined for reporting purposes, the $\$ 10$ million R\&D transaction would appear as part of the combined revenue of the companies. $^{7}$

\footnotetext{
${ }^{6}$ As before, R\&DCOR is name used only for expositional purposes, and does not correspond to any actual company.

7 At the macroeconomic level, the $\$ 10$ million R\&D transaction would be treated as investment in the U.S. national income and product accounts, though not as part of the core GDP accounts until 2013 (Robins and Moylan (2007)). The United Nation's System of National Accounts has also endorsed the capitalization of R\&D.
} 
Both of the preceding scenarios deal with externally purchased technology. Consider, now, the following situation in which R\&DCOR is actually a subsidiary of PHARMA. R\&DCOR produces exactly the same R\&D as in the preceding case, worth the same $\$ 10$ million, but now the R\&D is produced inside PHARMA and there is no external market transaction to validate the internal flow of value. Under current accounting practice, the $\$ 10$ million disappears from the revenue line of the income statement, because current practice treats the internal production of the R\&D as an intermediate input, not as the output of an investment good. Thus, the accountants record a current R\&D expense of $\$ 8$ million and suppress the $\$ 2$ million profit earned by the independent $R \& D$ producer of the preceding scenario into the overall operating surplus. In other words, there is a fundamental asymmetry in accounting practice: $R \& D$ is capitalized when the R\&D is produced externally but expensed when it is produced internally.

What do PHARMA's books look like when this asymmetry is removed? By analogy with the hypothetical example above, the $\$ 4.9$ billion in current R\&D outlays, reported on line 6 of Table 1, would be treated as an investment and added to top-line revenues. Also by analogy with the example, the $\$ 4.9$ billion outlay would be increased by the return to the capital used in producing the R\&D (the analogue of $\$ 2$ million R\&DCOR profit of the hypothetical example). The actual magnitude of this return is unknown, and we therefore use an imputation procedure that allocates total operating surplus to R\&D according to R\&D's share in current expenses. This procedure attributes a further $\$ 2.3$ billion to the cost of $R \& D$, giving a total investment cost of $\$ 7.2$ billion. 
This is the cost side of the investment and if PHARMA is assumed to make its investment decisions using the discounted present value approach, the $\$ 7.2$ billion is also the present value of the future profits on the investment. By symmetry with tangible capital, we combine the $\$ 7.2$ billion with PHARMA's $\$ 29.6$ billion revenue from goods sold to get a new top-line figure of $\$ 36.9$ billion in the column labeled "+R\&D" in Table 1.

\section{B. The "New" View of Financial Accounting: A Closer Look}

We have made the case that tangible and intangible assets should be treated symmetrically for accounting purposes, but the case of R\&D investment is actually more complicated because of the long gestation lags noted by DiMasi (2008) and because of the greater uncertainty about the expected income stream than tangible investment. Berndt et. al. (2006) show that only 40 percent of drugs that start the pre-clinical process make it to the clinical stage (the Phase I, II, and III trials of the FDA regulatory process), and only 8 percent of the drugs make it into the market place. Given these odds, much of PHARMA's $\$ 7.2$ million R\&D investment will disappear before it earns a return. The very high degree of uncertainty about outcomes, particularly in the early stages of a research project, might be better characterized by a Schumpeterian or "animal spirits" model of the investment decision, with only a tenuous link between ex ante cost and ex post returns.

Our $\$ 7.2$ billion estimate does not include the opportunity cost of the money tied up in the investments during the long gestation period. This opportunity cost depends 
on the costs and survival experience of individual drug development project, and is therefore hard to estimate. An important piece of evidence, in this regard, is provided by DiMasi, Hansen, and Grabowski (2003), who estimate that the average cost of bringing a drug to market is $\$ 802$ million, and that about half of that amount reflects the time-value of money. ${ }^{8}$ We should in principle adjust the $\$ 7.2$ billion for the time value of money, but the adjustment suggested by the results of DiMasi et. al. is so large that we decided to err on the side of conservatism and note only that our estimate of the annual cost is probably underestimated by a significant amount.

\section{Depreciation and Asset Valuation}

As with plant and equipment, $R \& D$ investments depreciate in value over time.

There is, however, an important difference. Machines lose value because they are used up in production due to wear, tear, and accident, or because of the obsolescence arising from the development of superior types of machinery. R\&D capital, on the other hand, is more closely tied to the output it generates and is therefore subject to obsolescence arising from competition from superior types of output, not superior inputs, as in the machinery case. There is also another dimension not shared with tangible capital. R\&D knowledge is largely a non-rival public good whose benefits can

8 These issues are also problems for tangibles, but to a lesser degree. For example, structures often take several years to build, from the planning through the construction stages of development, and money is tied up in the investment that imposes additional costs (and risk). However, the problems posed by the gestation lags in tangible assets are generally not of the same magnitude as the lags in pharmaceutical $R \& D$. The value of the tangible investment is normally recorded at the point at which it is completed and ready for transfer to the buyer. The transaction price thus includes a time-value adjustment in the final cost. R\&D investments, on the other hand, are self-constructed by the firm, and what is reported on the financial statement is the cost of the R\&D in progress, and not the complete project. There is thus no point at which an actual market-based time-value adjustment is made. 
accrue to other users without diminishing the quantity available to the originator. The value of the R\&D to the originator, on the other hand, is limited to the commercial value that can be extracted from the investment. If the knowledge diffuses to competitors, that value is eroded as competition leads to lower product prices. Some degree of protection to the originator is promoted, but not assured, by copyrights and patents, and by secrecy, but diffusion almost always occurs at some point, and this leads to the deprecation in the original cost of the investment.

The commercial life-cycle of the products developed by R\&D is the primary determinant of the depreciation rate of successful R\&D programs, and there is also the depreciation arising from the unsuccessful programs. It is therefore not surprising that the literature on this subject has produced a broad range of estimates that vary from around 10 percent to 25 percent (CHS (2006), Mead (2007)). The recent study by Hall (2007) suggests that the range of uncertainty could be even wider. Faced with this problem, we somewhat arbitrarily select an amortization procedure near the midpoint of the range in the literature and amortize each investment dollar (as it is spent) over a ten-year average life, using a pattern that declines slowly in the early years of the period and accelerates at the end.

The amortization of the R\&D stock adds a depreciation charge of $\$ 3.2$ billion to the income statement of Table 1 (column 2, line 11). This offsets some of the $\$ 7.2$ billion increase in "revenue" and results in before-tax income of $\$ 10.9$ billion (line 15$)$. Taxes are assumed to be unaffected when $R \& D$ is capitalized (that is, $R \& D$ is assumed to be expensed for tax purposes), so after-tax income on line 17 is now $\$ 9.5$ billion ( $\mathrm{a}$ 73 percent increase over the after-tax income of conventional accounting). Earnings 
per share increase from $\$ 2.03$, the amount when $R \& D$ is expensed, to $\$ 3.52$ when $R \& D$ is capitalized..$^{9}$

We also use our amortization procedure to estimate stock of R\&D capital on the balance sheet. We use a perpetual inventory method in which each year's investment in R\&D (e.g., \$7.2 billion in 2006) added to the preceding year's stock, and adjust for the depreciation of that stock. R\&D investments are initially recorded in the historical prices, and, as prices change, each year's investment needs to be expressed in constant prices in order to insure comparability. We use the price deflator in BEA's R\&D satellite account (see Robbins and Moylan (2007)) to convert R\&D investment from historical prices to current prices. ${ }^{10}$ We also adjust the annual depreciation estimates for price changes. ${ }^{11}$ This procedure yields an estimate of the constant price R\&D stock in each year, which we then reflate to current (not historical) prices using the BEA R\&D price series. The result is the $\$ 38.6$ billion R\&D stock recorded in Table 2 (column 2, line 9). This is important to emphasize the expected commercial value to PHARMA of its R\&D stock.

The assumption of a 10-year write-off period is, at best, a guess based on the bits of econometric evidence in the literature on R\&D, and may not apply to the case of

\footnotetext{
${ }^{9}$ It is important to note that capitalizing intangibles does not necessarily increase after-tax incomes and EPS. In companies where R\&D programs are declining, the amortization cost may exceed the amount added to the top line from current expenditures. In this situation, capitalizing R\&D may reduce EPS (see Lev (2001)).

10 We do not adjust the value of tangible assets from historical prices to current prices, because current accounting practice records tangible assets only at historical prices, with only occasional revaluation for price changes. This introduces a potential bias in the balance sheet estimate of assets. The size of the bias is suggested by BEA estimate that the current value of the fixed assets in the U.S. corporate business sector in 2006 was some 50 percent greater than the corresponding historical cost.

${ }^{11}$ We use our depreciation estimates to adjust both the income statement and the balance sheet. Strictly speaking, this is an inconsistent procedure unless depreciation has the geometric (declining-balance) form. Our procedure is not geometric and this introduces an inconsistency into the analysis, but the error is bound to be quite small compared to all the other uncertainties about the depreciation process.
} 
PHARMA. For one thing, it implies that all of the value of an investment from any year is gone after 10 years, and this is not consistent with the data on project survival. As a robustness check, we computed an alternative R\&D stock using the same general procedures but with a 20-year write-off period rather than the 10-year life as above. This alternative assumption of amortization results in an estimated stock of R\&D capital of $\$ 55.2$ billion, some $\$ 16$ billion greater than the previous estimate. Changes of this magnitude indicate that the estimates of Table 1 and 2 clearly depend on the magnitude of this uncertain parameter.

\section{Organizational and Human Assets}

R\&D is not the only type of intangible expenditure in the innovation process. Pharmaceutical companies typically have large marketing budgets designed, in part, to launch new products and PHARMA is no exception. It spent $\$ 1.6$ billion on advertising in 2006 and this is only part of the total marketing expenses. ${ }^{12}$ Some fraction of these expenditures are used to establish new drugs in the market place, and, once established, the resulting brand equity is an asset to the firm. By analogy with R\&D expenditures, this asset also belongs on the balance sheet of the company.

This view of marketing expenditures contrasts with the popular view that the marketing efforts of pharmaceutical companies are unproductive and merely serve to drive up the cost of drugs to the consumer. This view implicitly assumes that a good drug will sell itself, implying a rapid and costless dissemination of information. In fact,

12 This estimate uses advertising spending in 2006 of four companies: Bristol-Myers Squibb, Johnson and Johnson, Pfizer, and Wyeth. The other two companies provide no advertising data in 2006. 
the up-take of new drugs is often slow even when they turn out to be highly efficacious, and even when drug companies make considerable marketing efforts. One rationale for capitalizing some fraction of the marketing expenditures is that a company will not undertake the substantial cost of bringing a new drug to market (recall the $\$ 802$ million estimate of DiMasi, Hansen, and Grabowski (2003)), unless the company expects to sell enough of it to at least cover its full costs. Seen this way, the marketing of a new drug is a complementary coinvestment with R\&D and therefore part of the innovation process.

PHARMA also invests in organizational development (e.g., strategic planning, new management systems) and worker training. ${ }^{13}$ Brynjolfsson, Hitt, and Yang (2000, 2002) and Brynjolfsson and Hitt (2005) note that much of the IT spending in the 1990s was a coinvestment with expenditures for organizational development. These investments were, in part, intended to increase the effectiveness of corporate management, and the evidence in Bloom and van Reenan (2006) suggests that they also increase the value of a company. By implication, a fraction of such expenditures should be treated as capital for accounting purposes. A number of papers report similar results for worker training (Bassi et. al. (2002), Black and Lynch (2005)).

Expenditures for brand equity and organizational development are reported on most financial statements, so we borrow the CHS procedures and translate their approximate proportions of brand equity and organizational development investment into a corresponding fraction of SG\&A spending. This leads us to impute about 30

\footnotetext{
13 For the nonfarm business sector as a whole, $\mathrm{CHS}$ estimate that the value of brand equity was $\$ 161$ billion in 2003 , and $\$ 425$ billion for the other forms of organizational capital.
} 
percent of PHARMA's total SG\&A outlays in 2006 to investment in organizational capital. The result is an additional $\$ 4.1$ billion on the top line of PHARMA's income statement, bringing the total revenue inclusive of all intangible to $\$ 41.0$ billion. These estimates are shown in the last column of Table 1 (labeled "+ ORG K").

Organizational investments depreciate over time for a variety of reasons. Brand equity loses value when new goods appear in the market place or the marketing programs of competitors cut into market share, and human capital erodes through worker attrition and with the adoption of new products, processes, and business models. Management competencies erode for many of the same reasons. There is a debate over the appropriate depreciation rates for each intangible asset (CHS (2006)), and there is little information on how PHARMA's SG\&A is split among different types of organizational investments. Consequently, we adopt the simple assumption (based on $\mathrm{CHS}$ ) that each investment dollar is amortized over a six year period, again using a pattern that declines slowly in the early years of the period and accelerates at the end.

Using these procedures, we estimate that the depreciation/amortization of organizational capital amounted to $\$ 3.5$ billion in 2006 . When applied to the $\$ 4.1$ billion increase in revenue, after-tax income rose by $\$ 0.6$ billion to a grand total of $\$ 10.1$ billion.

Moving to the balance sheet, the estimated stock of organizational capital was found to be $\$ 16.3$ billion (column 3, line 10 of Table 2). When added to the $\$ 38.6$ billion in R\&D assets, own-produced intangibles exceed the $\$ 50.9$ billion in conventional assets. And, this comparison ignores the fact that $\$ 16.7$ billion of the latter are actually purchased intangibles and goodwill, implying that the grand total for all intangible capital 
is $\$ 71.6$ billion, or 68 percent of all assets. Most of these intangible assets are related to technological knowledge, brand equity, and organizational know-how, so it is not unreasonable to conclude that PHARMA is essentially a knowledge-based operation. PHARMA has only $\$ 10.1$ billion in plant and equipment.

\section{E. A Decomposition of the Sources of PHARMA's Market Valuation}

According to the Compustat data set, the stock market valued PHARMA at $\$ 102.9$ billion in 2006, a figure that greatly exceeds the conventional shareholder equity of $\$ 26.7$ billion (ex intangibles). The size of the gap can be measured by Tobin's average "q", the ratio of the stock market value to the book value of equity, or its inverse, which indicates the fraction of the stock market values explained by the book value of equity. These metrics are shown in lines 18 and 19 of Table 2 . They reveal that the traditional "10k" measure of shareholder equity explains only 26 percent of PHARMA's stock market value. ${ }^{14}$

Conventional accounting practice regards this gap as a combination of goodwill and identifiable intangibles. Rather than assuming a priori that it is so, we have inserted our cost-based estimates of intangibles into the gap and let the data determine how much is due to these intangibles and how much remains unexplained. We find that shareholder equity (inclusive of our intangibles) jumps to $\$ 81.7$ billion, a figure far closer

\footnotetext{
14 These estimates refer to the year 2006. The average market capitalization of the six companies that make up PHARMA fell to $\$ 75$ billion on "Black Friday", October 10, 2008, at which point the contemporary book value of equity explained 40 percent on the market value. The market value recovered to $\$ 84$ billion on October 20, and the percentage explained fell to 35 percent. While these figures assign a larger role to book value, there is still a large book-to-market gap left unexplained even during a period of extreme stock market turbulence.
} 
to the stock market's appraisal of the company. The corresponding measure of Tobin's "q" falls to 1.26 and shareholder equity now explains 79 percent of PHARMA's stock market value in 2006.

This result carries an interesting implication for the average rate of return to equity (Tobin's "q" times the inverse of the price/earnings ratio). Our estimates for PHARMA show that the conventionally measured return on equity is 21 percent when intangibles are excluded, and this falls to 14 percent when intangibles are included in both the numerator and denominator of the rate of return ratio. This is a much more modest rate of return on equity, and it is even smaller, 7 percent, when intangible assets are added to the denominator, but not the numerator. This version measures the direct (cash) return on equity when all the capital that generated the income is counted. Intangible assets do not explain the entire price-to-book gap. Some part of the remaining gap may reflect the volatility of the stock market, with its episodes of exuberance and pessimism. Another part may reflect a "Schumpeterian" gap between the ex ante cost-based estimates of the paper value and the ex post innovation rents earned by PHARMA. PHARMA represents the highly successful innovators in the industry, and one aspect of this success is that PHARMA is able to identify drug discovery programs that generate ex post super-normal profits. Since the probability of developing a successful drug is quite low, the drug-discovery industry is populated with less successful ventures. A more representative sample of the industry would tend to show more modest ex post returns and thus a smaller gap between market value and book value. 
Some part of the remaining gap may reflect other problems with the way that some balance sheet items are measured. Three sources of bias have already been noted. First, the balance sheet values tangible assets at the historical price when the asset was built or acquired, and ignores the inflation after the original investment. As previously noted, BEA estimates suggest that the balance sheets of U.S. firms understate nonresidential business plant and equipment by around 50 percent, implying that another $\$ 5$ billion would be added to the balance sheet if we apply that ratio to PHARMA's plant and equipment in 2006.

Second, the 10-year write-off period we assumed for R\&D investments may be too short. If a 20-year write-off period were used instead, the R\&D stock would be $\$ 16.6$ billion larger.

Third, there has been no adjustment for the time-value of money. The DiMasi estimate suggests that for successful projects the time-value of money almost equals the direct cost. However, only eight percent of the projects are successful, suggesting a smaller multiplier for all projects. If we use 20 percent as the appropriate multiplier for PHARMA, and apply it to the $\$ 55.2$ billion of the R\&D stock, the additional write-up in value is $\$ 11$ billion.

The sum of the last three factors adds $\$ 32.6$ billion to equity and, together, they explain more than the remaining price-to-book gap of $\$ 21.3$ billion. This overshoot could signal an error in the preceding adjustments, but it also reflects the fact that the component companies of PHARMA performed poorly in the stock market since 2001. Investors may be pessimistic about the "fecundity" of R\&D programs and may be concerned about regulatory risk. 
Other sources of error may bias the results in the opposite direction. We might have allocated too much of SG\&A costs or operating surplus to R\&D and organizational structure. But, however imprecise these estimates are, and they certainly are imprecise, it is reasonable to conclude that own-produced intangible investments are important in explaining the valuation of PHARMA.

\section{F. Some Pros and Cons of the New View}

It is important to recognize that neither the "old" nor "new" view of the income statement is uniquely correct. The annual sales and the corresponding ex post profits reported on the conventional statements provide important ex post information about success of the firm in the market place. Adding $\$ 11.4$ billion of implicit intangible income to actual sales may reveal something about the future prospects of the company, but it does not help illuminate how well the company's product are selling in the current year, and may actually obscure this issue. Moreover, the "new view" estimates of intangibles are inaccurate. They are based on imputations rather than on market transactions, and are inferred from the cost of investment.

On the other hand, treating R\&D as an expense can obscure a company's true long-run position. For example, many start-up biotechnology companies spend millions of dollars developing a new drug and go many years without earning significant revenues. Some of these start-ups become very profitable because their R\&D programs pay off, but by excluding R\&D capital from the financial statements, none of this success is anticipated. 
Moreover, if a more mature company wants to give the appearance of good economic health during rough times, the company can increase its current profits by cutting its R\&D expenses. ${ }^{15}$ In the case of Table 1 , if the entire $\$ 4.9$ billion current R\&D cost were eliminated, before-tax income in conventional income statement would increase by this amount. Assuming an unchanged average tax rate, 2006 EPS would jump from $\$ 2.03$ to $\$ 3.47$. This strategy, however, does not work when $R \& D$ is capitalized, because EPS in column 3 would fall from $\$ 3.74$ to $\$ 2.66$ if current R\&D were zeroed out. This occurs because the income statement must deduct the amortization costs from past R\&D (line 11) to get before-tax income. More is lost from the top line than is offset by a reduction in current cost.

\section{A Broader Look at Financial Accounting with Intangibles}

Is the case of PHARMA representative? After all, PHARMA is a collection of the more successful companies in the U.S. economy. Are intangible assets as important for other companies as they are for PHARMA? To answer this question, we extracted a sample of U.S. 617 corporations from the Compustat database of 9885 firms and constructed tables for this sample that parallel the items in Tables 1 and $2{ }^{16}$ Only those

\footnotetext{
15 A lack of transparency is needed in order for this strategy to work, otherwise the financial markets would recognize the loss in future value, if any, associated with a reduction in investment in R\&D. Lev $(2001,2003)$ and Bassi et. al. (2004) argue that this tends to be the case, with the implication that current accounting practice creates a disincentive for investment in R\&D and other expensed intangibles.

16 The Compustat data are derived from company financial statements, adjusted to harmonize them across companies. Thus they do not necessary match the data on the company reports. There are wellknown risks in using financial statements for time-series and cross-sectional comparisons (see Hall (2007)). Accounting rules change over time, and merger and acquisitions (and spinoffs) occur that can greatly affect the income statements and balance sheets of a company. Comparisons over time, as well
} 
companies with R\&D and SG\&A expenditures for most of the sample period (19882006) were included. By restricting our sample to firms with a more-or-less continuous record of R\&D spending, we bias our results in favor of intangibles. Around 60 percent of the companies in the 617 sample come from just six of the 41 two-digit industries and include the largest R\&D performers. ${ }^{17}$ It is therefore not surprising that the estimates in Tables 3 and 4 are comparable to those for PHARMA in Tables 1 and 2. The fraction of 617 firms' market value explained by conventional equity alone is 31 percent and this increases to 75 percent when "own" intangibles are included. The comparable figures for PHARMA are 26 percent and 79 percent.

\section{Are Intangibles Really Capital Assets?}

We noted earlier in this paper that the long gestation periods for the R\&D programs of the pharmaceutical industry virtually force the conclusion that they should be regarded as capital investments, and that this conclusion is reinforced by the body of evidence linking intangibles to company valuation and productivity. ${ }^{18}$ This conclusion

as the perpetual inventory estimates of the $R \& D$ and organizational capital stocks, must be interpreted with these caveats in mind.

17 To check the difference between the 617 R\&D-intensive companies and the rest, we constructed the equivalent to Tables 3 and 4 for the entire sample less those companies. A comparison of these tables with the estimates of Tables 3 and 4 indicate the 617 firms with a complete record are far more intangibleintensive relative to plant and equipment. One problem with this comparison is that missing data in the latter sample were assigned a zero, whereas the few cases of missing data in the 617-firm sample were interpolated. The problem of missing data is the principal reason that we do not analyze the complete sample in this paper.

18 This literature includes studies relating financial market value to R\&D (e.g., Hall (1993), Hall and Hall (1993), Lev (2001)); managerial and organizational capital (see Bloom and Van Reenen (2006), Bryjolfsson and Hitt (2005)), advertising (Hall (1993), Ayanian (1983)), and worker training (Abowd et. al. (2005), Bassi et. al. (2004)). 
can be checked using the Compustat data underlying our intangible stock estimates, supplemented by data on stock market prices.

The difficulties in using stock market data to value intangibles are now well known (Hall (2005) provides a cogent overview of the problems). The boom-bust stock market cycle evident in Figure 2 contrasts sharply with the much smoother trends in the intangible stock variables, which are built up from successive investments over the years and therefore do not change rapidly, even in periods where investment spending is volatile. Any attempt to forge a tight link between the two is therefore subject to a certain amount of econometric peril.

This being said, we can at least check for correlations between the key variables. To do this, we further narrowed our sample of R\&D-intensive companies to a timeseries, cross-section panel of only the 422 companies that have a complete record of all data series for the years 1997-2006. This smaller sample excludes those companies in the 617 data set for which some observations had to be extrapolated or interpolated. We then use these data to estimate a model in which the value of a company's shares, $V_{i, t}$, depends on the book value of the company's equity, $E_{i, t}$, the estimated value of its R\&D capital, $R_{i, t}$, its organizational capital, $O_{i, t}$, and the average price-earning ratio $Z_{i, t}$ of the principal industry to which the company belongs (the latter is included in order to account for shifts in financial market optimism about future earnings). The linear form of this model is

$$
V_{i, t}=\alpha+\beta E_{i, t}+\gamma R_{i, t}+\theta O_{i, t}+\lambda Z_{i, t}+\varepsilon_{t}
$$

Variants of this model are found in the literature linking intangibles to stock market valuation (see, for example, the discussion in Brynjolfsson and Hitt (2005)). Some 
studies use Tobin's "q" in place of $V_{i, t}$; the tangible capital stock replaces $E_{i, t}$ in others; and various types of intangible stocks or flows are used instead of $R_{i, t}$ and $O_{i, t}$, along with different ancillary variables.

The issue of causality is a potential problem in most of these models (including ours). This problem arises because, while lower rates of investment in intangibles may indeed lead to a lower market valuation (the usual interpretation), it may also be the case that a deterioration in business prospects leads both to a lower market valuation and a lower propensity to invest. This direction of causality may arise from a common economy-wide shock to both variables, like a recession. In this regard, it has been noted in the economic literature that R\&D investment tends to be pro-cyclical. ${ }^{19}$ Or, the problem could arise from firm-specific events in which the diminished (or enhanced) prospects for a company jointly affect its market value and its investment programs.

The narrower objective of this paper is to test current accounting practice versus the "new view" that intangibles have capital value. Current practice assumes that the coefficients of the intangible stocks in equation (1) should not be correlated with market value, whereas the "new view" asserts that these coefficients should be positive and significantly different from zero. If they are, the case for capitalizing intangibles is enhanced. Furthermore, in the Hall (2005) zero-rent economy with prefect foresight, no

\footnotetext{
19 Economic explanations of this pro-cyclical behavior of R\&D are discussed in Barlevy (2007). The incentive to cut R\&D spending during periods of falling profits because R\&D is expensed, noted by Lev (2001) and Bassi et. al. (2004), may contribute to this problem by offering a way to boost EPS in the near term. However, one problem with these explanations is the inherent nature of research programs. They often involve multi-year commitments, witness the DiMasi data on gestation lags in pharmaceutical R\&D, and are frequently undertaken in competition with the programs of other firms. Canceling or slowing this sort of R\&D program involves more than simply short-run cost considerations.
} 
omitted variables, and correctly priced equity, $\alpha$ and $\lambda$ should be zero and $\beta$ should equal one.

To test these hypotheses, we carried out the regression indicated by the valuation equation, in both its level form, as shown above, and in its natural logarithms (in which case the valuation equation is assumed to be multiplicative). The first column of Table 5 gives the results of imposing the restriction that intangibles do not affect market value. The estimate of $\beta$ is 3.59 and is statistically significant, indicating that a $\$ 1$ increase in the book value of equity increases market value by an expected $\$ 3.59$. The average annual industry price/earning ratio also shows a significant positive effect on valuation. However, the constant term, $\alpha$, is not statistically significant. Dummy variables for each year are also included as a separate control for general market effects. The R-squared statistic is respectably large.

The next column introduces the two stocks of intangible capital, but omits equity. The results are, again, statistically significant and indicate a large effect, particularly for the stock of organizational capital, providing evidence in favor of the capitalization hypothesis. On the other hand, when equity and intangibles are used together, the estimated coefficients of all variables fall, and that of the stock of organizational capital becomes statistically insignificant though still positive. However, there is a very high correlation between the equity and organizational variables in the data, so it is hard to sort out the separate contributions of the two variables. It is worth recalling, here, that the equity and $R \& D$ variables are derived from reported data whereas the organizational capital is imputed as a faction of SG\&A. 
Much the same pattern is observed in the last three columns of Table 5, which report results for the multiplicative form of the valuation equation. The key variables are transformed to the natural log form, with the result that the parameters are now interpreted as elasticities. Equity by itself is again a strong variable, with the magnitude of the coefficient now implying that a one percent change in the amount of equity leads approximately to a one percent change in stock market value. The R\&D and organizational capital variables, by themselves, are both strongly significant and their combined coefficients are close to one. Again, when all three variables are included in the regression, all coefficients fall but the sum continues to be close to one. The Rsquared statistics in this specification are higher than in the preceding table.

A number of other regressions were run for various separate industries and years, with varying results. Organizational capital is a strong explanatory variable in the chemical and pharmaceuticals industry but has the wrong sign in Instruments. However, the general industry patterns are consistent with the more aggregate Table 5. Combined with evidence from past studies, we interpret our results as lending statistical support to the case for capitalizing intangibles.

\section{Concluding Remarks}

Financial accounting data are neither inherently right nor wrong. They are only more or less useful for the questions that people want answered. Some questions involve "agency" issues that shareholders and other interested parties seek to monitor the actions of managers. This has inclined accounting principles toward a conservatism 
that stresses accuracy in valuation and relies on data generated by arms-length market transactions.

One consequence of this conservatism is that hard-to-value assets like intangibles are excluded from the accounts. According to our estimates, these excluded assets explain some 40 to 50 percent of the 2006 market value of R\&Dintensive companies in the U.S., and appear significant in explaining the market-tobook-value puzzle. The intrinsic value of corporate America is a lot larger than its book equity suggests. This has an important implication for fair value accounting: if the book value of equity is used as a more accurate indicator of fair value in preference to markto-market rule during sharp downturns in the stock market, the former will greatly understate fair value by a potentially large amount. Another implication is that the exclusion of intangible capital from financial statements gives companies an incentive to cut back on R\&D spending during economic downturns, since these expenditures currently add nothing to assets or equity and raise earnings in the short run.

The excluded assets also present a different perspective on corporate debt and the degree to which a company has leveraged its equity. The bottom lines of Tables 2 and 4 show that debt-equity ratios fall significantly when intangibles are included in both the numerator and denominator (from 0.91 to 0.30 in the case of PHARMA, and from 1.46 to 0.61 for the larger sample). One implication is that the use of debt to finance the construction of a company's "own" intangible assets magnifies the conventionallymeasured debt-equity ratio. In this situation, the liability is added to the balance sheet, while the intangible assets it finances are omitted. 
Our findings have yet another implication for the return on corporate equity. The pharmaceutical industry appears to have a large return, 21 percent, when investment in intangibles is excluded, but the rate of return on equity falls to a more modest 14 percent when intangibles are added to the numerator and denominator. The return is even lower, 7 percent, when conventional after-tax net income is compared to a measure of equity that reflects the huge investments in R\&D and marketing. We find similar results for the larger sample of R\&D intensive companies. Again, it is important to count all the capital that matters.

The issue of omitted intangibles goes beyond the mechanical problem of adding or modifying data on company financial statements. A company's accounting data are a reflection of its actual economic performance, and this performance is determined in the long run by the quality and execution of its business model. How the data are organized and reported should ideally reveal the nature of this model and the corresponding organizational structure. Current accounting practice falls short of this ideal because it implicitly portrays the company primarily as a producer of goods and services. Mandel (2006) puts his finger on this problem when he observes that, while the Apple iPod is made in China, "Where the gizmo is made is immaterial to its popularity. It is great design, technical innovation, and savvy marketing that have helped Apple Computer sell more than 40 million iPods." Mandel goes on to observe that by ignoring the value of Apple's large investments in R\&D and marketing, that is, by imposing a pure production function view of Apple, the company is implicitly portrayed as simply a reseller of this phenomenally successful product. 
In fact, the modern corporation is most often a complex organization that develops, produces (or, increasingly, arranges for others to produce), and markets a range of products. Characterizing this process in all its complexity goes far beyond the simple production function framework to a more realistic model of the firm of the sort suggested by Penrose (1959). Developing metrics for this more elaborate description of the firm requires a parallel development in the way a company's performance data are organized and presented. Recognizing that expenditures on product development and organizational capability are investments in a company's future rather than current expenses is an important step in this direction. 


\section{References}

Abowd, John M., John Haltiwanger, Ron Jarmin, Julia Lane, Paul Lengermann, Kristin McCue, Kevin McKinney, and Kristen Sandusky, "The Relation among Human Capital, Productivity, and Market Value: Building Up from Micro Evidence." In Measuring Capital in the New Economy, C. Corrado, J. Haltiwanger, and D. Sichel, eds., Studies in Income and Wealth, Vol. 65. Chicago: The University of Chicago Press, 2005.

Advisory Committee on Measuring Innovation in the $21^{\text {st }}$ Century, Innovation Measurement: Tracking the State of Innovation in the American Economy, A Report to the Secretary of Commerce, U.S. Department of Commerce, January 2008.

Ayanian, Robert, "The Advertising Capital Controversy." Journal of Business 56 (3), 1983, 349-364.

Barlevy, Gadi, "On the Cyclicality of Research and Development," American Economic Review 97 (4), March, 2007, 1131-1164.

Bassi, Laurie, Paul Harrison, Jens Ludwig, and Daniel McMurrer, "The Imact of U.S. Firms' Investments in Human Capital on Stock Prices," unpublished, June 2004

Berndt, Ernst R., Adrian H.B. Gottschalk, and Matthew W. Strobeck, "Opportunities for Improving the Drug Development Process: Results from a Survey of Industry and the FDA", in AB Jaffe, J Lerner and S Stern eds., Innovation Policy and the Economy, Vol. 6, Cambridge, MA, MIT Press for the NBER, 2006, pp. 91-121.

Bernstein, Jeffrey, I. and Theofanis P. Mamuneas, "R\&D Depreciation, Stocks, User Costs and Productivity Growth for U.S. Knowledge Intensive Industries," mimeo, Carleton University, 2004.

Black, Sandra and Lisa M. Lynch, "Measuring Organizational Capital in the New Economy," in Measuring Capital in the New Economy, C. Corrado, J. Haltiwanger, and D. Sichel, eds., Studies in Income and Wealth, Vol. 65. Chicago: The University of Chicago Press, 2005, 205-234.

Black, Sandra and Lisa M. Lynch, "Human Capital Investments and Productivity," American Economic Review, 86 (2), May, 1996, 263-267.

Blair, Margaret M., and Steven M.H. Wallman, Unseen Wealth: Report of the Brookings Task Force on Intangibles, Brookings Institution Press, Washington D.C., 2001

Bloom, Nick, and John Van Reenen, "Measuring and Explaining Management Practices Across Firms and Countries," National Bureau of Economic Research Working Paper 11948, January 2006. 
Brynjolfsson, Erik., and Lorin M. Hitt, "Remarks," In Measuring Capital in the New Economy, C. Corrado, J. Haltiwanger, and D. Sichel, eds., Studies in Income and Wealth, Vol. 65. Chicago: The University of Chicago Press, 2005, 567-575.

Brynjolfsson, E., Hitt, L. and Yang, S., "Intangible Assets: Computers and Organizational Capital," Brookings Papers on Economic Activity,1, 2002,137-181.

Brynjolfsson, Erik., Lorin M. Hitt, and Shinkyu Yang, "Intangible Assets: How the Interaction of Information Technology and Organizational Structure Affects Stock Market Valuations." Cambridge, Mass: MIT Working paper, 2000.

Corrado, Carol, John Haltiwanger, and Daniel Sichel, "Introduction," in Measuring Capital in the New Economy, C. Corrado, J. Haltiwanger, and D. Sichel, eds., Studies in Income and Wealth, Vol. 65. Chicago: The University of Chicago Press, 2005, 1-9.

Corrado, Carol, Charles Hulten, and Daniel Sichel, "Measuring Capital and Technology: An Expanded Framework." In Measuring Capital in the New Economy, C. Corrado, J. Haltiwanger, and D. Sichel, eds., Studies in Income and Wealth, Vol. 65. Chicago: The University of Chicago Press, 2005, 11-41.

Corrado, Carol, Charles Hulten, and Daniel Sichel, "Intangible Capital and Economic Growth," National Bureau of Economic Research Working Paper 11948, January 2006.

DiMasi, Joseph A., "New Drug Development in the United States from 1963 to 1999," Clinical Pharmacology and Therapeutics, 69, 5, 2001, 151-85.

DiMasi, Joseph A., Ronald W. Hansen, and Henry G. Grabowski, "The Price of Innovation: New Estimates of Drug Development Costs," Journal of Health Economics, 22 (2), 2003, 151-186.

Grabowski, Henry G., and Dennis C. Mueller, "Industrial Research and Development, Intangible Capital Stocks, and Firm Profit Rates," The Bell Journal of Economics, 9, 2 Autumn, 1978, 328-343.

Hall, Bronwyn H., "Measuring the Returns to R\&D, The Depreciation Problem," National Bureau of Economic Research Working Paper 13473, October 2007

Hall, Bronwyn, "The Stock Market's Valuation of R\&D Investment During the 1980's," American Economic Review, 82, 2, May 1993, 259-264.

Hall, Bronwyn and Robert E. Hall, "The Value and Performance of U.S. Corporations," Brookings Papers on Economic Activity,1, 1993, 1-50. 
Hall, Robert E., "Remarks," In Measuring Capital in the New Economy, C. Corrado, J. Haltiwanger, and D. Sichel, eds., Studies in Income and Wealth, Vol. 65.

Chicago: The University of Chicago Press, 2005, 557-562.

Hall, Robert E. (2001a). "Struggling to Understand the Stock Market." American Economic Review Papers and Proceedings 91 (May): 1-11.

Hall, Robert E. (2000). "e-Capital: The Link between the Stock market and the Labor Market in the 1990s." Brookings Papers on Economic Activity, 2 ,2000, 73-118.

Hall, Robert E. (2001b). "The Stock Market and Capital Accumulation." American Economic Review 91 (December): 1185-1202.

Lev, Baruch, "Remarks on the Measurement, Valuation, and Reporting on Intangible Assets," FRBNY Policy Review, Federal Reserve Bank of New York, September, 2003, 17-21.

Lev, Baruch, Intangibles: Management, Measurement, and Reporting, Brookings Institution Press, Washington D.C., 2001.

Lev, Baruch, and Suresh Radhakrishnan, "The Valuation Organizational Capital," In Measuring Capital in the New Economy, C. Corrado, J. Haltiwanger, and D. Sichel, eds., Studies in Income and Wealth, Vol. 65. Chicago: The University of Chicago Press, 2005, 73-99.

Mandel, Michael, "Why The Economy Is a Lot Stronger Than You Think," Business Week, February 13, 2006, 62-70.

Mead, Charles Ian, "R\&D Depreciation Rates in the 2007 R\&D Satellite Account," Bureau of Economic Analysis/National Science Foundation, 2007 R\&D Satellite Account Background Paper, U.S. Department Of Commerce, November 2007.

Penrose, Edith T., The Theory of the Growth of the Firm, Basil Blackwell Mott, 1959.

Robbins, Carol A., and Carol E. Moylan, "Research and Development Satellite Account Update Estimates for 1959-2004 New Estimates for Industry, Regional, and International Accounts," Survey of Current Business, October 2007, 49-92.

System of National Accounts 1993. Commission of the European Communities, International Monetary Fund, Organization for Economic Co-operation and Development, United Nations, and World Bank. 


\section{TABLE 1 \\ 'NEW VIEW' INCOME STATEMENT ${ }^{1}$ \\ BASED ON SIX COMPANY AVERAGE ("PHARMA”) \\ 2006 (\$ BILLIONS)}

1. CONVENTIONAL REVENUE

2. OWN PRODUCTION OF R\&D ${ }^{3}$

3. OWN PRODUCTION OF ORG. CAPITAL ${ }^{3}$

4. TOTAL ADJUSTED REVENUE (L1+L2+L3)

5. CONVENTIONAL COST OF REVENUE

6. CURRENT COST R\&D ${ }^{4}$

7. CURRENT COST OF SG\&A ${ }^{4}$

8. TOTAL CURRENT COST (L5+L6+L7)

9. OPERATING SURPLUS (L4-L8)

10. DEPRECIATION ALREADY ACCOUNTED FOR ${ }^{5}$

11. AMORTIZATION OF OWN R\&D ${ }^{6}$

12. AMORTIZATION OF OWN ORG. CAPITAL ${ }^{6}$

13. ADJ. OPERATING SUPLUS (L9-L10-L11-L12)

14. NET INTEREST AND OTHER ADJUSTMENTS

15. BEFORE-TAX INCOME (L13-L14)

16. INCOME TAX PAID ${ }^{7}$

17. AFTER-TAX INCOME

$\begin{array}{rrr}10 k^{2} & +R \& D^{2} & +O R G K^{2} \\ & & \\ \$ 29.6 & \$ 29.6 & \$ 29.6 \\ \$ 0 & \$ 7.2 & \$ 7.2 \\ \$ 0 & \$ 0 & \$ 4.1 \\ \$ 29.6 & \$ 36.9 & \$ 41.0\end{array}$

$\$ 6.4$

$\$ 4.9$

$\$ 6.4$

$\$ 6.4$

$\$ 8.8$

$\$ 20.2$

$\$ 4.9$

$\$ 4.9$

$\$ 8.8$

$\$ 8.8$

$\$ 20.2$

$\$ 20.2$

$\$ 9.5$

$\$ 16.7$

$\$ 20.8$

$\$ 1.9$

$\$ 1.9$

$\$ 1.9$

$\$ 3.2$

$\$ 3.2$

$\$ 0.0$

$\$ 3.5$

$\$ 0.0$

$\$ 11.6$

$\$ 12.2$

$\$ 0.7$

$\$ 0.7$

$\$ 0.7$

$\$ 6.9$

$\$ 10.9$

$\$ 11.5$

$\$ 1.5$

$\$ 1.5$

$\$ 5.5$

$\$ 9.5$

$\$ 10.1$

$\$ 2.03 \quad \$ 3.52 \quad \$ 3.74$

\section{EARNINGS PER SHARE}

Note 1: Based on S\&P Compustat data and authors' calculations. Detail may not add up due to rounding error. Note 2: Column 1, designated "10k", contains conventional financial data from Compustat; Column 2, designated “+R\&D”, adds R\&D data to the data of column 1; Column 3, designated “Org K”, adds organizational capital data to column 2.

Note 3: "Own Production of R\&D” is shadow value of the investment in R\&D made by the company. It is equal to current cost of R\&D on line 6, all of which is considered to be a capital expenditure, plus markup for profit (imputed fraction of line 9 attributable to production of R\&D). “Own Production of Org. Capital” is shadow value of the investment in organizational capital made by the company. It is equal to approximately $30 \%$ of current SG\&A costs on line 7, the portion considered to be a capital expenditure, plus markup for profit (imputed fraction of line 9 attributable to production of organizational capital).

Note 4: Current cost of R\&D (line 6) and organizational capital (line 7) is the outlay for labor and materials, plus applicable depreciation and amortization. This differs from the shadow values on lines 3 and 4 (see note 3).

Note 5: Conventional Depreciation and amortization are allocated to costs on lines 5 to 7 . They are subtracted, here, in order to arrive at net income.

Note 6: The amortization of own R\&D and organizational capital arises when these items are capitalized, as in columns 2 and 3. R\&D is amortized over a 10 year useful life with a quasi-hyperbolic write-off pattern. Organizational capital is amortized over a 5 year useful life with a quasi-hyperbolic write-off pattern.

Note 7: Assumes that the implicit income from R\&D and organizational capital is not taxed. 
TABLE 2

'NEW VIEW'ASSET ACCOUNTS ${ }^{1}$

BASED ON SIX COMPANY AVERAGE ("PHARMA")

2006 (\$ BILLIONS)

CONVENTIONAL BALANCE SHEET ${ }^{2}$

1. CURRENT ASSETS

2. PLANT AND EQUIPMENT

3. PURCHASED INTANGIBLES

4. GOODWILL

5. OTHER LONG TERM ASSETS

6. TOTAL ASSETS (L1+L2+L3+L4+L5)

7. TOTAL LIABILTIES

8. EQUITY

\section{ADJUSTMENTS FOR OWN INTANGIBLES}

9. R\&D CAPITAL ${ }^{4}$

10. ORGANIZATIONAL CAPITAL ${ }^{4}$

11. ASSETS ADJ. FOR OWN INTANG. (L6+L9+L10)

12. EQUITY ADJ. FOR OWN INTANG. (L8+L9+L10)

$\begin{array}{rrr}10 k^{3} & +R \& D^{3} & + \text { ORG } K^{3} \\ & & \\ \$ 19.8 & \$ 19.8 & \$ 19.8 \\ \$ 10.1 & \$ 10.1 & \$ 10.1 \\ \$ 8.0 & \$ 8.0 & \$ 8.0 \\ \$ 8.7 & \$ 8.7 & \$ 8.7 \\ \$ 4.3 & \$ 4.3 & \$ 4.3 \\ \$ 50.9 & \$ 50.9 & \$ 50.9 \\ & & \\ \$ 24.2 & \$ 24.2 & \$ 24.2 \\ \$ 26.7 & \$ 26.7 & \$ 26.7 \\ & & \\ 10 k & +R \& D & + \text { ORG K } \\ & & \\ \$ 0.0 & \$ 38.6 & \$ 38.6 \\ \$ 0.0 & \$ 0.0 & \$ 16.3 \\ \$ 50.9 & \$ 89.5 & \$ 105.8 \\ \$ 26.7 & \$ 65.3 & \$ 81.6 \\ & & \\ 10 k & +R \& D & + \text { ORGK } \\ & & \\ \$ 102.9 & \$ 102.9 & \$ 102.9 \\ \$ 127.1 & \$ 127.1 & \$ 127.1 \\ \$ 103.0 & \$ 103.0 & \$ 103.0 \\ \$ 26.9 & \$ 65.4 & \$ 81.7 \\ \$ 16.8 & \$ 55.3 & \$ 71.6 \\ & & \\ 10 k & +R \& D & + \text { ORG K } \\ & & \\ 3.85 & 1.58 & 1.26 \\ 0.26 & 0.63 & 0.79 \\ 0.91 & 0.37 & 0.30 \\ 0.21 & 0.15 & 0.14\end{array}$

13. MARKET VALUE OF EQUITIES $S^{5}$

14. FINANCIAL VALUE OF FIRM (L13+L7) ${ }^{6}$

15. CORE FINAN. VALUE OF FIRM (L14-L1-L5)

16. CORE ASSETS (L11-L1-L5)

17. TOTAL INTANGIBLE ASSETS (L3+L4+L9+L10)

\section{VALUATION RATIOS}

18. TOBIN'S EQUITY QE (L13/L12)

19. PERCENT MV VALUE EXPLAINED $\left(1 / \mathrm{Q}_{\mathrm{E}}\right)$

20. DEBT/EQUITY RATIO (L7/L12)

21. RETURN ON EQUITY (T1 L17/L12)

Note 1: Based on S\&P Compustat data and authors' calculations. Detail may not add up due to rounding error. Note 2: Conventional balance sheet items recorded at historical cost.

Note 3: See note 2 of Table 1.

Note 4: See note 2 of Table 1 for amortization assumptions. Note also that valuation of intangibles is at current, not historical, cost.

Note 5: Average monthly market value of outstanding equities.

Note 6: Average monthly market value of outstanding equities plus balance sheet liabilities. 
TABLE 3

S\&P CORPORATIONS WITH CONTINUOUS R\&D

'NEW VIEW' INCOME STATEMENT ${ }^{1}$ 2006 (\$ BILLIONS)

\begin{tabular}{lrrr}
\hline & $10 k$ & $+R \& D$ & + ORG K \\
& & & \\
1. CONVENTIONAL REVENUE & $\$ 4899$ & $\$ 4899$ & $\$ 4899$ \\
2. OWN PRODUCTION OF R\&D & $\$ 0$ & $\$ 220$ & $\$ 220$ \\
3. OWN PRODUCTION OF ORG. CAPITAL & $\$ 0$ & $\$ 0$ & $\$ 399$ \\
4. TOTAL ADJUSTED REVENUE (L1+L2+L3) & $\$ 4899$ & $\$ 5119$ & $\$ 5518$ \\
& & & \\
5. CONVENTIONAL COST OF REVENUE & $\$ 3283$ & $\$ 3283$ & $\$ 3283$ \\
6. CURRENT COST R\&D & $\$ 165$ & $\$ 165$ & $\$ 165$ \\
7. CURRENT COST OF SG\&A & $\$ 658$ & $\$ 658$ & $\$ 658$ \\
8. TOTAL CURRENT COST (L5+L6+L7) & $\$ 4106$ & $\$ 4106$ & $\$ 4106$ \\
& & & \\
9. OPERATING SURPLUS (L4-L8) & $\$ 793$ & $\$ 1013$ & $\$ 1412$ \\
10. DEPRECIATION ALREADY ACCOUNTED FOR & $\$ 191$ & $\$ 191$ & $\$ 191$ \\
11. AMORTIZATION OF OWN R\&D & $\$ 0$ & $\$ 134$ & $\$ 134$ \\
12. AMORTIZATION OF OWN ORG. CAPITAL & $\$ 0$ & $\$ 0$ & $\$ 318$ \\
13. ADJ. OPERATING SURPLUS (L9-L10-L11-L12) & $\$ 602$ & $\$ 688$ & $\$ 769$ \\
& & & \\
14. NET INTEREST AND OTHER ADJUSTMENTS & $\$ 18$ & $\$ 18$ & $\$ 18$ \\
15. BEFORE-TAX INCOME (L13-L14) & $\$ 584$ & $\$ 670$ & $\$ 751$ \\
16. INCOME TAX PAID & $\$ 192$ & $\$ 192$ & $\$ 192$ \\
17. AFTER-TAX INCOME & $\$ 392$ & $\$ 478$ & $\$ 559$ \\
& & & \\
18. EARNINGS PER SHARE & $\$ 2.48$ & $\$ 3.03$ & $\$ 3.54$ \\
\hline
\end{tabular}

1. Data from 617 R\&D-intensive U.S. corporations. See notes to preceding tables. 
TABLE 4

S\&P CORPORATIONS WITH CONTINUOUS R\&D

'NEW VIEW' BALANCE SHEET ${ }^{1}$

2006 (\$ BILLIONS)

CONVENTIONAL BALANCE SHEET

1. CURRENT ASSETS

2. PLANT AND EQUIPMENT

3. PURCHASED INTANGIBLES

4. GOODWILL

5. OTHER LONG TERM ASSETS

6. TOTAL ASSETS (L1+L2+L3+L4+L5)

7. TOTAL LIABILITIES

8. EQUITY

ADJUSTMENTS FOR OWN INTANGIBLES

9. R\&D CAPITAL

10. ORGANIZATIONAL CAPITAL

11. ASSETS ADJ. FOR OWN INTANG. (L6+L9+L10)

12. EQUITY ADJ. FOR OWN INTANG. (L8+L9+L10)

COMPANY VALUATION

13. MARKET VALUE OF EQUITIES

14. FINANCIAL VALUE OF FIRM (L13+L7)

15. CORE FINAN. VALUE OF FIRM (L14-L1-L5)

16. CORE ASSETS (L11-L1-L5)

17. TOTAL INTANGIBLE ASSETS (L3+L4+L9+L10)

VALUATION RATIOS

18. TOBIN'S EQUITY $\mathrm{Q}_{E}(\mathrm{~L} 13 / \mathrm{L} 12)$

19. PERCENT MV VALUE EXPLAINED $\left(1 / \mathrm{Q}_{\mathrm{E}}\right)$

20. DEBT/EQUITY RATIO (L7/L12)

21. RETURN ON EQUITY (T3 L17/L12)
$10 k+R \& D \quad+O R G K$

$\$ 1726 \quad \$ 1726 \quad \$ 1726$

$\$ 1389 \quad \$ 1389 \quad \$ 1389$

$\$ 210 \quad \$ 210 \quad \$ 210$

$\$ 604 \quad \$ 604 \quad \$ 604$

$\$ 778 \quad \$ 778 \quad \$ 778$

$\$ 4707 \quad \$ 4707 \quad \$ 4707$

$\$ 2795 \quad \$ 2795 \quad \$ 2795$

$\$ 1910 \quad \$ 1910 \quad \$ 1910$

$10 k+R \& D \quad+O R G K$

$\$ 0 \quad \$ 1239 \quad \$ 1239$

$\$ 0 \quad \$ 0 \quad \$ 1448$

$\$ 4707 \quad \$ 5946 \quad \$ 7394$

$\$ 1910 \quad \$ 3149 \quad \$ 4597$

$10 k+R \& D \quad+O R G K$

$\$ 6146 \quad \$ 6146 \quad \$ 6146$

$\$ 8941 \quad \$ 8941 \quad \$ 8941$

$\$ 6437 \quad \$ 6437 \quad \$ 6437$

$\$ 2203 \quad \$ 3442 \quad \$ 4890$

$\$ 814 \$ 2053 \quad \$ 3501$

$10 k+R \& D \quad+O R G K$

$\begin{array}{lll}3.22 & 1.95 & 1.34 \\ 0.31 & 0.51 & 0.75 \\ 1.46 & 0.89 & 0.61\end{array}$

$0.21 \quad 0.15$

0.14

1. Data from 617 R\&D-intensive U.S. corporations. See notes to preceding tables. 
TABLE 5

DETERMINANTS OF MARKET VALUE

S\&P SAMPLE OF 422 COMPANIES WITH

COMPLETE RECORD OF R\&D

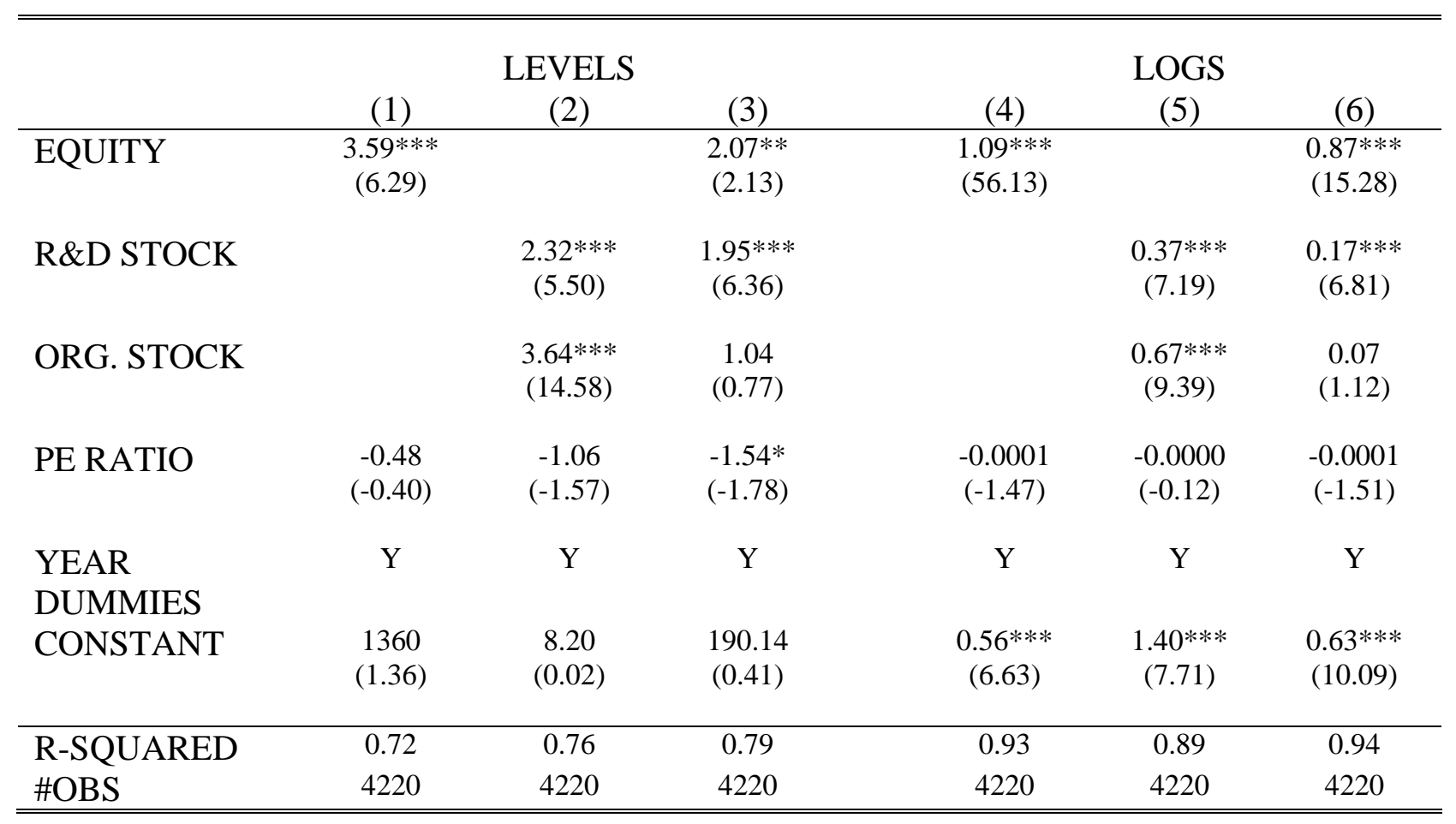

Notes: Firm-level panel data drawn from Compustat covering the period 1997 to 2006. The dependent variable is the average of the monthly market value of a firm. The results in columns (1), (2), and (3) refer to specification in which the variables are in levels. The results in columns (4), (5), and (6) refer to specification in which market value, equity, R\&D stock, and the stock organizational capital (“Org” stock) are transformed to natural logarithms. The P/E ratio is the corresponding industry average for each company. Standard errors are clustered by 2-digit industries. 


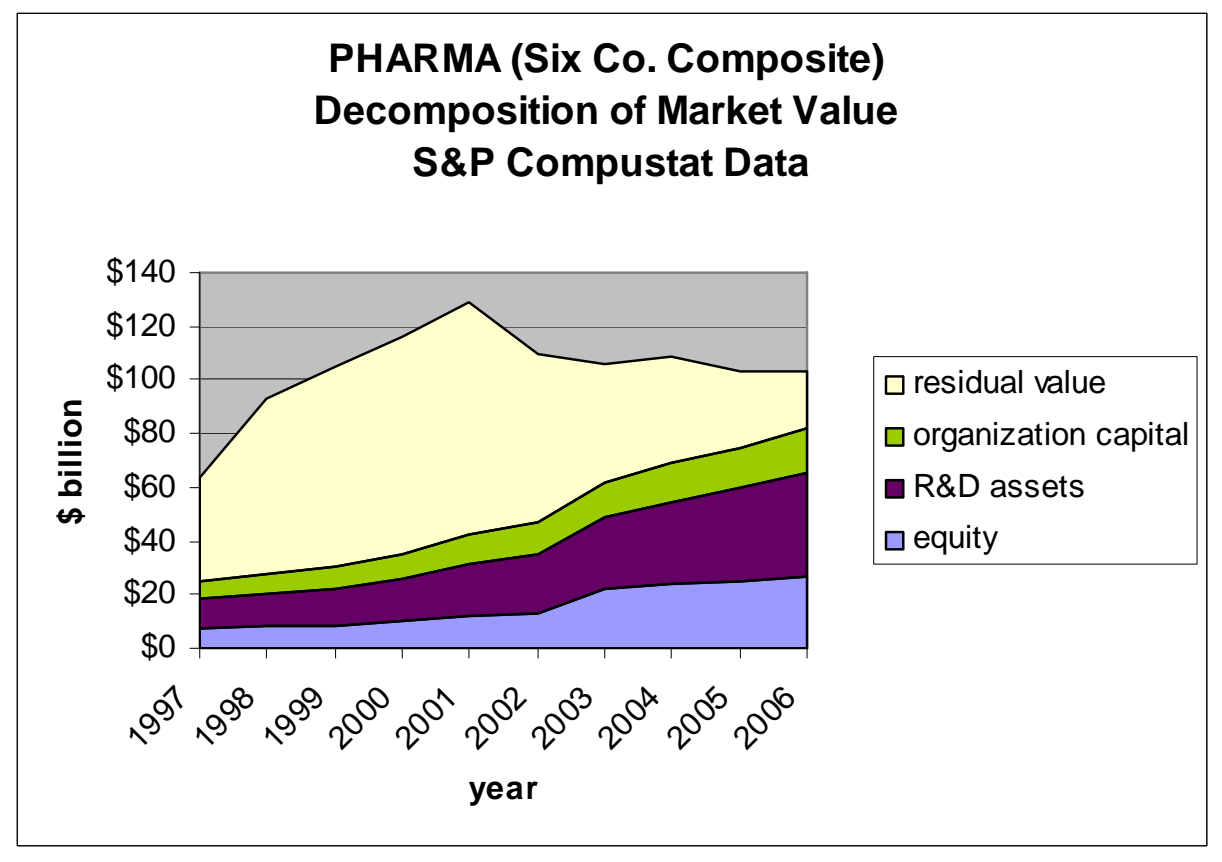

\section{FIGURE 1}

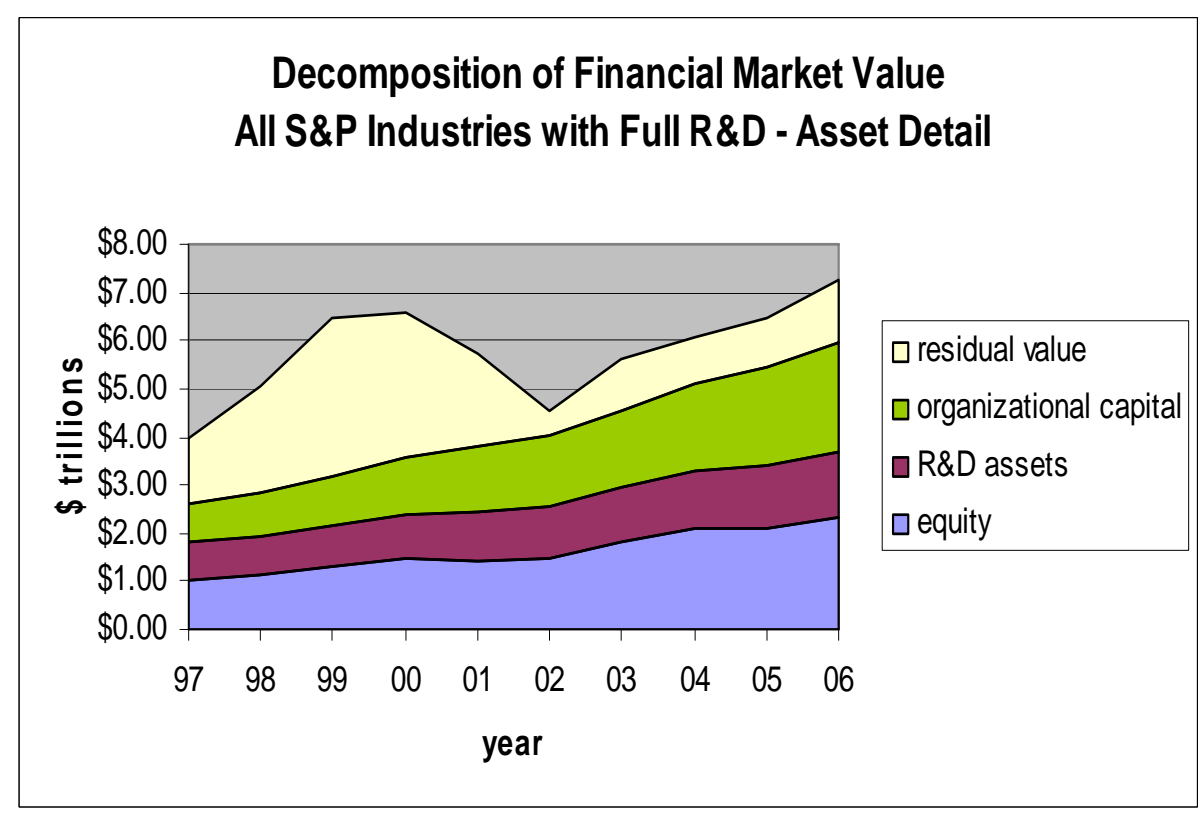

\section{FIGURE 2}

